\title{
„So Far and No Further!” - Thoughts on Legitimacy of the Hungarian Border Fence
}

\section{Robert Bartko}

Assoc. Prof. Dr., University of Győr, Faculty of Law and Political Sciences, Department of Criminal Sciencies

\section{Abstract}

In 2015, Hungary was unexpectedly affected by the irregular migration flow, which marked a beginning of a new era in the history of the European migration - in terms of its quality and its size. The European countries have been forced to admit irregular migrants from the developing countries in increasing numbers. Mass migration - not only because of its irregular nature, but also because of its qualitative and quantitative changes - has created a major challenge for the authorities concerning the legal respones. In many countries, including in Hungary, the public opinion related to the irregular migration has forced the legislators to take the necessary measures against it in order to protect the public safety. In Hungary - although the irregular migration is a multifaceted phenomenon, therefore the legal respones affect many parts of the internal legal system - the law enforcement and the criminal law have been focused by the legislator. In the face of the increased migratory pressure - in order to protect the security of Hungary - the Hungarian government has accepted a package of the legal measures. The first step was the construction of the physical border fence at the Serbian-Hungarian and the Croatian-Hungarian border, and as a second stage the Hungarian Parliament adopted the Act CXL of 2015 which created the legal framework on protection of the mentioned border fence (for example creating new statutory definitions). Whereas not only the Hungarian Criminal Code, but also the Act of Criminal Procedure were amended by the mentioned act, it is necessary to deal whether the construction of the border fence can be considered as a legitimate step with special reference to the international and European commitments of Hungary. The mentioned question is considered as a preliminary one, because in default of legitimacy all of the measures adopted by the Hungarian Parliament and the Government would be considered unlawful. The paper deals with the mentioned problem and analyzes the legitimacy of the Hungarian border fence taking into consideration the international and European standards. ${ }^{1}$

Keywords: Hungarian border fence, irregular migration, border barrier, fight against the irregular migration in Hungary, migratory situation in Hungary, FRONTEX, Schengen Borders Code, Treaty on European Union.

\footnotetext{
${ }^{1}$ Supported by the Bolyai János Research Scholarship and by the New National Excellence Program Nr. ÚNKP - 19-4-SZE-2 of the Hungarian Ministry of Innovation and Technology.
} 


\section{Introduction}

In 2015, Hungary was unexpectedly affected by the irregular migratory flow, which marked a beginning of a new era in the history of the European migration. As a result of emigration, European countries have been forced to admit irregular migrants from the developing world in increasing numbers (TRIANDAFYLLIDOU \& MAROUKIS, 2012, p.1). Between 2009 and 2010, about 100,000 illegal immigrants were caught in the act at the borders of the Member States each year (MOREHOUSE \& BLOMFIELD, 2011, p. 8.). In 2013, the total number of non-EU nationals intercepted at the border of EU Member States was 92,575 (GAINCHE, 2015, p. 105.). As the migration crisis intensified, in 2014 this number had increased to 276,113 people at the panEuropean level. This represented an increase of more than $138 \%$ compared to previous years (Europol, 2016, p. 7.).

Contrary to previous trends, between 2014 and 2015, partly from the Balkan states and from the destabilized countries in the Middle East and North Africa, mass emigration began to the countries of the European Union, which meant a big challenge not only for the Member States themselves, but also the European integration. This trend has not changed significantly in recent years. In 2015 and 2016, the number of illegal immigrants entering the European Union rose to unprecedented levels. According to FRONTEX data, in 2015 the EU states recorded nearly 1,800,000 illegal border crossings at the height of the migration crisis, while in 2016 still extremely high, 511,047 irregular border crossings were detected (Frontex, 2018, p. 8.).

Mass migration, not only because of its irregular nature, but also because of the unprecedented qualitative and quantitative transformation of the response to be given by some Member States, has created a major challenge not only for border control, but also for the internal law enforcement,- and the public health authorities, furthermore, the other internal social organizations. In many Member States, including in Hungary, public opinion related to the irregular migration has forced the legislators to take quick and effective actions against it. In Hungary - although the irregular migration is a multifaceted phenomenon (Hegyaljai, 2016, p. 12.), therefore the legal respones affect many parts of the internal legal system - the law enforcement and the criminal law have been focused by the legislator. However, criminalization is not a widespread response in the European Union. Typically, in Western European states, the illegal border crossing and the illegal residence are not considered as criminal offenses (Guild, 2016, p. 24.). Although, there is a shift towards criminalization (Lévay, 2017, pp. 153-162.) of certain forms of illegal migration, it is not considered as a criminal offense in the domestic law of the most Member States. It is, of course, another question that according to the so-called "marginalization theory", illegal immigrants who are marginalized in the country of destination often drive their fate towards committing crimes (Leekers, 2012, p. 17.), which should be judged in accordance with the substantive criminal law of that state.

It shall be emphasized that as a primary response to the phenomenon of illegal immigration itself, the criminal legal action reacts more likely to that criminal activities based on illegal migration, such as trafficking in human beings, smuggling of human beings and related organized crime (MITSILEGAS, 2015, p. 48.). The illegal immigration has been used by the mentioned crimes in order to reinforce its status in the European Union, taking advantage of Europe's openness and its declared fundamental freedoms (Galateanu, 2017, p. 601).

In accordance with the above-mentioned fact, in the political dialogue, illegal immigration is often regarded as a threat to state sovereignty as well as to public security, whereby the states 
have the right to protect their borders. The emphasis of the mentioned aspects is justified by the need on the one hand to respond to the conduct - videlicet the illegally enters the territory of a foreign state - itself, and on the other hand to the security challenges concerning the illegal stay (Spena, 2017, p. 354).

\section{The legal antecedents of the Hungarian border fence}

Since the beginning of 2015, when the migratory pressure has intensified in Hungary, the idea of the more effective legal measure against the irregular immigration has become part of the political dialogue in Hungary. If we look only at the number of asylum seekers between 2014 and 2015 , it is clear, that by July 2015 , this number had risen to 78,000 , compared to the about 43,000 asylum applications filed in 2014 . By the end of 2015 , the number of asylum seekers was close to 180,000 (Póczik, 2018, p. 11). In this mentioned, increased migratory pressure, the Hungarian government has adopted a package of legal measures, mainly for the sake of the security of Hungary. The first step was the establishment of a physical border barrier and creating legal regulations facilitating its construction. As second step the Hungarian Parliament adopted the Act CXL of 2015 which created the legal framework for managing mass immigration by amending a lot of internal acts. Of course, the Hungarian legislator also intended to protect the physical border fence by legal means. As the legislator pointed out in the part of the general legislative justification of the above-mentioned Act in 2015: "the state borders can be protected only by the installation of ever more serious facilities. The function of these facilities is not only to complete the state's self-defense, but also to signal that the state has right to self-defense, and that right must be respected by everyone."

For the above-mentioned reasons, stopping the irregular migratory flow and establishing the internal legal items in order to reach the mentioned aim was declared by the Hungarian Government in 2015. The first step in the realization of this legal policy was the decision of the Government 1401/2015, which set a deadline of 1 July 2015 on the one hand to "prepare for the construction of a 4-meter high border barrier on the Serbian-Hungarian border at about $175 \mathrm{~km}$ length" and on the other hand to make the necessary legal measures in order to protect it.

After the mentioned decision - as a second step, before the entry into force of the necessary amendments concerning the Hungarian criminal law and criminal procedure law - the Hungarian legislator had the goal to protect the construction of the border fence. Due to the mentioned political aim the Government adopted the decision 213/2015 in August which punished with fine that acts which violated partly the construction site of the border fence and partly its construction. The mentioned fine - depending on its gravity - was from 30.000,-HUF to 500.000 ,-HUF.

Following these precedents, the Hungarian Parliament adopted the Act CXL of 2015 on 4 September 2015. This act introduced significant changes in several areas in the Hungarian internal law. The reason for the legislation was multi-directional. On the one hand, logistical and other social tasks related to immigrants crossing the Hungarian border meant a significant economic burden for the country, which had to be remedied. On the other hand, the goal of legal policy was to protect state sovereignty, and to develop a definite border protection policy in order to express the state's self-defense function. It should be noted that - as Tamas Hoffman a senior researcher at the Institute of Law of the Hungarian Academy of Sciences said - the application of a temporary physical border lock is not "devilish" either. In its view, a State 
is entitled, by virtue of its sovereignty, to defend its own borders in this way, provided that it meets its obligations under international law (Póczik, 2018, p. 15).

The above-mentioned act amended a lot of parts of the Hungarian legal system, not only the criminal law and the criminal procedural law, but also the legal regulation concerning the migration policy and also the Act on State Borders. As the above legislation created a criminal legal protection for the border barrier and introduced special procedural rules in the Hungarian Act on Criminal Procedure as well, it is reasonable to consider whether the construction of the border fence itself can be considered lawful. The paper would like to find the answer to the question whether the building of the physical border lock at the external borders can be considered as lawful measure in accordance with international and EU commitments of Hungary.

\section{The Hungarian legal history of the unlawful border crossing}

It shall be emphasized that any individual conduct in order to enter the territory of Hungary through the installed border barrier is necessarily unlawful. However, the irregular or unlawful border crossing was not an unknown act in Hungarian legal history. In the Act V. of 1978 which was the first Hungarian Criminal Code - called Code Csemegi - such a provision which punished the mentioned act cannot be found (Hautzinger, 2016, p. 190). However, it is interesting that the Act XL of 1879 in its Article 70 - among the offenses against of public security - regulated the conduct of returning to the territory of Hungary without permission of the authorities during the period of expulsion (Tóth, 2016, p. 225). It can be underlined that in that first period the unlawful entry could not be considered as itself an offense, just if it was committed by an expelled person. After the mentioned act the Act XVIII of 1940 resulted a kind of tightening in the mentioned question. It amended the Act VI. of 1903 on Passport Management by creating a criminal offense referring to that case if the perpetrator crossed the border unlawful by breaching the legal requirements on using of the passport.

However, the Act V of 1961, which repealed the Special Part of the Csemegi Code, significantly amended the criminal policy. According to the mentioned act it shall be punished by imprisonment of between six months to five years on the basis of Articel 203 Par. (1) if the perpetrator entered Hungary without permission or unlawful, or by using such a passport which obtained unlawfully.

The Act IV of 1978 on the third Hungarian Criminal Code - from its entering into force qualified the unlawful crossing border as a criminal offence with the above-mentioned content till 1 January 1990. From this time the elements of mentioned crime supplemented by the case of armed crime as a special method of committing the crime.

Nowadays, the unlawful crossing border is also a sanctioned conduct however, not by the Hungarian Criminal Code but by the Articel 204 Par. (1) of the Act II of 2012 on Administrative Penal Code - as the Code states: any person who crosses or attempts to cross without permission or unlawful the Hungarian state border perpetrates the illegal crossing of the state border. Therefore, the first question is, whether it is possible to take action, even by means of criminal law, against a migrant arriving at the country's borders who wants to enter the territory of Hungary unlawful through the border barrier, and the second is whether it is possible to defend Hungary itself against irregular migration at the country's external borders by construction of the border barrier? 


\section{Interpretation of the Hungarian border barrier and our conclusions}

The state's right to self-defense is based on its sovereignty. States, if their international commitments do not limit it, can decide on the basis of their right to self-defense, how to protect their sovereign territory from persons who seek to enter it illegally. Therefore, a matter of fact that the protection of state borders is a right based on the sovereignty of the state, but also an obligation concerning its citizens. Articles 3-4 of the Treaty on European Union and the Treaty on Functioning of the European Union (hereinafter: the Treaty) are clear that the question analyzed above cannot be considered either the exclusive competence of the Union - these areas are: customs union; the establishing of the competition rules necessary for the functioning of the internal market; monetary policy for the Member States whose currency is the euro; the conservation of marine biological resources under the common fisheries policy and the common commercial policy - or shared competence with the Member States. However, it is important to underline that the Treaty also declares the prevention of and the fight against irregular migration as a clear objective of the EU in its Article 79. Par (1): „The Union shall develop a common immigration policy aimed at ensuring, at all stages, the efficient management of migration flows, fair treatment of third-country nationals residing legally in Member States, and the prevention of, and enhanced measures to combat, illegal immigration and trafficking in human beings"

However, in our view, the Regulation (EU) 2016/399 on a Union Code on the rules governing the movement of persons across borders (hereinafter: Schengen Borders Code) based on Article 77 Par. (1) Sec. (c) and Par. (2) Sec. (b) and (e) of the Treaty is also important. The Schengen Borders Code already states in Par. (6) of its Preamble that border control by the Member States at the external borders must contribute both to combating irregular immigration and trafficking in human beings and also to the internal security and public policy and public health of each Member State. Article 5 Par. (3) of the Schengen Borders Code deals with the protection of the external borders as an important task at Member State level, in accordance with the fundamental objectives set out in the Preamble. Therefore, the Member States should introduce in their national law sufficiently effective, proportionate and dissuasive sanctions for unauthorized crossing of external border at places other than border crossing points or at times other than the fixed opening hours. However, when establishing sanctions, Member States should pay attention to the exceptions based on Article 5 Par. (2) of the Schengen Borders Code and to the other international obligations. The mentioned exceptions are - for example - the followings: individuals or groups of persons in the event of an unforeseen emergency situation; individuals or groups of persons, where there is a requirement of a special nature for the occasional crossing of external borders outside border crossing points or outside fixed opening hours, provided that they are in possession of the permits required by national law and that there is no conflict with the interests of public policy and the internal security of the Member States.

Examining the exceptions, it can be emphasized that the members of the irregular migratory wave who intend to enter the country in a way that adversely affects the installed border barrier cannot be considered as an exemption declared by the Shengen Borders Code. Therefore in the cases the Member States provide for sanctions against such illegal entry.

It is necessary to declare that the above-quoted provisions of the Schengen Borders Code, and its regulations concerning the official checking on external borders do not prohibit for the Member States the use of an installed technical tool for border protection. This is also 
reinforced by the definition of the Schengen Borders Code on border surveillance and its more detailed definition in Article 13 Par. (1). According to the Shengen Borders Code the border surveillance also includes the prevention from circumventing border control. The Article 13 Par. (1) states that the purpose of border surveillance is (a) to prevent unauthorized persons from crossing the border, (b) to take the necessary measures against persons who wish to cross the border unlawful and to prevent the cross-border crimes. In order to achieve effective border surveillance, all of usable tools could not be regulated, but it would not make sense to regulate. Therefore, Article 15 of the Schengen Borders Code merely requires that the tools used shall ensure an efficient, high and uniform level of border control.

In other words, with regard to the protection of the external borders, the relevant provisions of the Schengen Borders Code require that: (1) Member States protect the external borders effectively and efficiently; (2) border surveillance activities shall be organized in such a way which can prevent illegal border crossings; (3) the Member States, when organize their border surveillance activities, shall use that means which can meet the requirements of the Schengen Borders Code at a high level; (4) the Member States shall regard to exceptions provided by the Code. Based on this cumulative set of requirements, according to our opinion the technical border barrier installed at the external borders of Hungary is not objectionable. Here it shall be highlighted that Regulation (EU) 2016/1624 of the European Parliament and of the Council on FRONTEX states in its Article 5 that FRONTEX shall cooperate with the national authorities for the purpose of implementing integrated border management, however, according to the last sentence of Article 5 Par. (1): „Member States shall retain primary responsibility for the management of their sections of the external borders."

At the same time, there have been also numerous humanitarian legal criticism - based on that thought that the member of the migratory flow can be considered as refugees - referring to on the one hand the border lock and to the other hand the Hungarian criminal law which provided legal protection for it. In order to examine this humanitarian legal arguments, it is necessary to deal with the provisions of the International Convention relating to the status of refugees adopted on 28 July 1951 and its Additional Protocol of 31 January 1967 (hereinafter: the Geneva Convention which was announced in Hungary by the Law decree 15 of 1989) the relevant regulations of the Treaty and the EU Charter of Fundamental Rights.

According to the Article 31 Par. (1) of the Geneva Convention, Hungary is under an obligation not to punish refugees who have come directly from a country where their life or liberty was endangered, because of unauthorized entry, provided that they report promptly to the authorities and justify their unauthorized entry. The European legal framework cited also regards the Geneva Convention as governing. The Article 78 Par. (1) of the Treaty orders the establishment of a common asylum policy (Witold, et.al., 2018, pp. 457-494) in the European Union in accordance with the provisions of the Geneva Convention. The Article 18 of the European Charter of Fundamental Rights, concerning the right to asylum, also declares that this right shall be guranateed with due respect for the rules of Geneva Convention and for the Treaty. Therefore, the question to be answered is whether the construction of a border barrier can be considered as a violation of the provisions of the Geneva Convention or not. According to the above-mentioned provision of the Geneva Convention, the international legal rule does not in itself preclude Hungary's right to create criminal sanctions in order to prevent irregular entry into Hungary. Namely, the mentioned provision attributes fundamental importance to the principle of directness. 
According to the Geneva Convention, Hungary undertook "only" not to criminalize illegal border crossing, which takes place directly from the territory of a state, where the life or freedom of the person or persons, who later is granted refugee status, was endangered at the require level declared by the Geneva Convention. Namely, due to the geographic characteristics of Hungary, and based on the nationality composition of the immigrants arriving and coming to Hungary, the violation of the principle of directness does not even arise, therefore, the establishment of the border barrier and the legislator's aim to ensure entering Hungary's territory legally, in a controlled manner, is not objectionable. The border barrier cannot be interpreted as an obstacle referring to the principle of directness regulated by the Geneva Convention. Furthermore, it is another question that the intention of an illegal immigrant who tries to enter the country's border through a border fence cannot be aimed at cooperation with the authorities. Therefore the condition - concerning the obligation to immediately report to the authorities - of the impunity guaranteed by the Geneva Convention cannot apply.

The unlawful crossing of the border fence in itself justifies the absence of the conditions required by the Geneva Convention. Thus, the Hungarian legislator has adopted important measures for not only the protection of external borders at European level, but also for the practical application of the Geneva Convention. The compatibility of the Hungarian legal solution with the European commitments is also confirmed by the above-mentioned Schengen Borders Code, which explicitly provides in its Article 5 Par. (3) for national legislation to introduce penalties, in accordance with their national law, for the unlawful crossing of external borders. The Schengen Borders Code also requires that these sanctions shall be proportionate, effective and dissuasive. In this context, it is important to point out that Article 3 Par. (2) of Directive 2008/115 of the European Parliament and of the Council also describes residence as an illegal stay as a result of an illegal border crossing contrary to Article 5 of the Schengen Borders Code.

The Hungarian literature has also often argued that border barrier, and the legal regulations based on it, can be considered problematic items in the light of the Rome Convention for the Protection of Human Rights and Fundamental Freedoms. The focus of this argument is one of the provisions concerning the expulsion. According to the Articel 60 Par. (2a) of the Hungarian Criminal Code, that person who is sentenced by imprisonment because of an crime against the border barrier shall expelled from the territory of Hungary. It shall be emphasized that Article 1 of the 7. Additional Protocol to the European Convention on Human Rights (hereinafter: the Rome Convention) deals with the guarantees for the expulsion of foreigners. At the same time, it is important to emphasize that the persons protected by the Additional Protocol are lawfully resident in the territory of a state acceding to the Rome Convention. For such persons, the system of expulsion rules is not based on automatism, and guarantees consistent with the Rome Convention have been included by the legislator in the Hungarian Criminal Code. However, that foreigners involved in a crime against the border barrier typically do not have a residence permisson in Hungary, and has no intent to cross the border legally, therefore, the construction of the border fence and creating the crimes against the border barrier by the Hungarian legislator in oder to protect on the one hand the fence installed, and on the other hand the European external borders and the Hungarian public security, cannot be considered as problematic measures. 


\section{References}

[1] EUROPOL (2016): European Union Terrorism Situation and Trend Report 2016.

[2] FRONTEX (2018): Risk Analysis for 2018.

[3] Galateanu, Oana (2017): Illegal Migration and the Migration Phenomenon at the Frontiers of Romania. Contemporary Readings in Law and Social Justice. Vol 9 (2),

[4] GuILD, E. et. al. (2016): Irregular Migration, Trafficking and Smuggling of Human Beeings: Policy Dilemmas in the EU. CEPS Paperback

[5] HAUTZINGER Zoltán (2016): Büntetőjogi tényállások a külföldiség és a migráció vonzásában. In. Hautzinger Zoltán (szerk.): A migráció bűnügyi hatásai. Magyar Rendészettudományi Társaság Migrációs Tagozat, Budapest

[6] Hegyaljai Mátyás (2016): Migráció, bünügy, nemzetközi kitekintés. In. Hautzinger Zoltán (szerk.): A migráció bünügyi hatásai. Magyar Rendészettudományi Társaság Migrációs Tagozat, Budapest

[7] Laure Basilien-GAINCHE, Marie (2015): Immigration Detention under the Return Directive: The CJEU Shadowed Lights. European Journal of Migration and Law, Vol. 17.

[8] LEEKERS, Arjen et. al. (2012): Crime among irregular immigrants and the influence of internal border control. Crime Law SocChange 2012. Vol. 58.

[9] LÉVAY Miklós (2017).: "Crimmigration" avagy kriminológiai kutatások a bevándorlás kriminalizálásáról. In: A tudós ügyész. Tanulmányok Bócz Endre 80. születésnapjára. Szerk.: Finszter Géza-Korinek László-Végh Zsuzsanna. HVG-ORAC, Budapest

[10] Mitsilegas, Valsamis (2015): The Criminalization of Migration in Europe. Challenges for Human Rights and the Rule of Law. Springer

[11] Morehouse, Christal\&Blomfield Michael (2011): Irregular migration in Europe. Migration Policy Institute, Washington DC

[12] Póczik Szilveszter (2018): A határzárral kapcsolatos büncselekmények elkövetőinek szociológiai vizsgálata a Csongrád megyei büntetőeljárások alapján. Kriminológiai Tanulmányok Vol. 55.

[13] SpenA, Alessandro (2017): A Just Criminalization of Irregular Immigration: Is it possible? Criminal Law and Philos, Vol. 11.

[14] Tóth Judit (2016): Hatékony, arányos, visszatartó? Az engedély nélküli határátlépés szankcionálása. In. Hautzinger Zoltán (szerk.): A migráció bűnügyi hatásai. Magyar Rendészettudományi Társaság Migrációs Tagozat, Budapest

[15] TRIANDAFYlliDou, A \& MARoukis, T. (2012): Migrants muggling: Irregular migration from Asia and Africa to Europe. Springer

[16] Witold Klaus, Miklós Lévay, Irena Rzeplinska, and Miroslav Scheinost (2018): Refugees and Asylum Seekers in Central European Countries: Reality, Politics and Creation of Fear in Societies. In: Helmut Kury, Slawomir Redo, Editors, Refugees and Migrants in Law and Policy. Challenges and Opportunities for Global Civic Education. Springer, Cham, 2018. 